\title{
LASER-ASSISTED, CRACK-FREE SURFACE MELTING OF LARGE EUTECTIC CERAMIC BODIES $§$
}

\author{
J. Gurauskis, V. Lennikov, G.F de la Fuente, R.I. Merino ** \\ Instituto de Ciencia de Materiales de Aragón, CSIC- Universidad de Zaragoza, \\ E-50009, Zaragoza, Spain
}

\begin{abstract}
The modification of ceramic surfaces by directional laser melting is interesting because it can eliminate surface defects and thus improve the ceramics mechanical performance, as long as one prevents the formation of cracks. The feasibility of surface modification by laser assisted melting on large $\mathrm{t}-\mathrm{ZrO}_{2}-\mathrm{Al}_{2} \mathrm{O}_{3}$ eutectic ceramic pieces was evaluated in this work. $0.4 \mathrm{~mm}$ thick, defect free, resolidified layers were obtained on plates of 40 mm width by preheating at $1200{ }^{\circ} \mathrm{C}$ and processing at $1000 \mathrm{~mm} / \mathrm{h}$ with a line-shaped $\mathrm{CO}_{2}$ laser beam and $580 \mathrm{~W} / \mathrm{cm}^{2}$ irradiance. The surface finish was smooth, free from overlapping-track roughness. The resolidified layer had eutectic microstructure with lamellae-type $\mathrm{Al}_{2} \mathrm{O}_{3}$ and tetragonal $\mathrm{ZrO}_{2}\left(\mathrm{t}-\mathrm{ZrO}_{2}\right)$ colonies. The fracture tests of the samples confirmed the absence of crack type resolidification defects and the removal of surface defects. Although no increase in average flexural strength was observed for surface resolidified samples, they showed significantly lower standard deviation.
\end{abstract}

Keywords: Laser remelting; $\mathrm{Al}_{2} \mathrm{O}_{3}-\mathrm{ZrO}_{2}$; Surfaces; Defects; Mechanical properties.

\footnotetext{
${ }^{\S}$ Post-print version of the article: Gurauskis J, et al. Laser-assisted, crack-free surface melting of large eutectic ceramic bodies. J. Eur. Ceram.

Soc. (2010), doi:10.1016/j.jeurceramsoc.2010.08.017

** Phone: +34 976 761333, Fax: +34 976 761229, e-mail: rmerino@unizar.es
} 


\section{INTRODUCTION}

The laser surface melting of a eutectic ceramic gives the possibility to modify surface properties and eliminate critical surface defects that may result in the improvement of the mechanical performance of the whole ceramic body. Laser melting and resolidification of ceramic surfaces has been used in the past with the objective of sealing porous ceramic refractories [1-4], changing the wettability of the surface [5], increasing wear resistance [6,7], modifying tribology properties [8], repairing of localized manufacturing defects [9], texturing the surface layer [10], producing functional coatings on ceramics [11], or modifying the pore architecture and thermophysical properties of thermal barrier coatings applying a combined plasma spraying with in-situ laser remelting process $[12,13]$ etc. It is difficult, however, to completely suppress crack development during processing, because of the large thermal gradients that the brittle material is subjected to during extremely localized heating by the laser beam. One of the obvious solutions to minimize these large thermal gradients is to perform the preheating of the zone or of the whole substrate to be treated. Zum Gahr and colleagues [14] were the first ones to explore this approach. They used furnace preheating of $\mathrm{Al}_{2} \mathrm{O}_{3}$ based ceramics (porous and relatively dense, TD 95\%) up to $1500{ }^{\circ} \mathrm{C}$ and observed significant reduction of processing cracks. Bradley et. al. [15] employed a different preheating approach based on direct zone preheating with oxygen/acetylene flame. As a result they obtained crack free densification of $\mathrm{Al}_{2} \mathrm{O}_{3}$ based refractory materials. Triantafyllidis et. al. [16] tried dual laser beam heating (one laser for preheating and another for melting) but encountered difficulties in reproducibility associated to the requirement of precise laser beam alignment. More recently, these authors explored the possibility of using wider laser beams (up to $12 \mathrm{~mm}$ 
in diameter) together with relatively low processing speeds (around $0.4 \mathrm{~mm} / \mathrm{s}$ ) without the need for preheating and found a window for melting where crack formation was avoided [17]. Large production rates are achieved, according to the previous reports, by combining ca. 3 to $10 \mathrm{~mm}$ wide laser beams with processing speeds above $0.4 \mathrm{~mm} / \mathrm{s}$ so that $2000 \mathrm{~cm}^{2}$ can be processed in one hour by successive track scanning. Although due to the nature of the substrate and because the solidification rate of the processed layer is high, the solidified crystals form dendrites and, quite frequently, generate interdendritic contraction porosity. Recently, Campana et. al. [18] attained surface melting and resolidification of porous eutectic ceramic tubes without the need of preheating, only at conditions where the resolidified layer was very thin (30 microns). Traverse solidification rates around $400 \mathrm{~mm} / \mathrm{h}$ were used, which are in the range of coupled eutectic growth of oxide eutectic ceramics (10 to $1000 \mathrm{~mm} / \mathrm{h}$ [19]). Cooling of the melt in this case was dominated by large forced convection. Although, as observed by Larrea et. al. [20] in the resolidification of $\mathrm{Al}_{2} \mathrm{O}_{3}-\mathrm{YSZ}$ eutectic ceramics, if thicker resolidified cermet layers are needed, preheating is unavoidable for this method.

A number of studies performed on directionally solidified oxide eutectics show improved mechanical behaviour at room and high temperatures due to the combination of a fine homogeneous microstructure together with clean and strongly bonded interfaces $[19,21,22]$. Laser assisted surface melting of eutectics has been applied to $\mathrm{Al}_{2} \mathrm{O}_{3}$-YSZ [20, 21], $\mathrm{Al}_{2} \mathrm{O}_{3}$-YAG [23], NiO-CaSZ [24] oxide systems and, more recently, to non-oxide systems [25], and their microstructure evaluated. In particular, fracture toughness [23] and wear resistance [6] of laser treated $\mathrm{Al}_{2} \mathrm{O}_{3}-\mathrm{YSZ}$ eutectic composition has been studied since the fabrication of smooth, $10 \mathrm{~mm}$ wide crack-free ceramic samples has been achieved using a high power diode laser with a line shaped beam. Dense ceramic substrates (95\%TD) in this case were preheated to a temperature 
of $980 \mathrm{C}^{\mathrm{o}}$ with a home-made small heating furnace coupled to the laser system. $\mathrm{Al}_{2} \mathrm{O}_{3}$ zirconia eutectics have another extra advantage to this technique, as the compound can be melt processed in air without severe bubble trapping in a wide range of solidification conditions.

A line shaped laser beam remelting approach combined with relatively low solidification rate required to obtain a suitable eutectic microstructure may be too slow a process for industrialization. Consequently, more intense laser beams, focused into longer line-shaped beams, are desirable. Moreover, as the full sample surface width is simultaneously covered by the focused laser line under these conditions, no surface curvature is generated due to the overlap of drop-shaped tracks, and macroscopically smoother surfaces can thus be fabricated. The implementation of this approach is, however, limited due to difficulties in the dimensional scaling of substrate to be treated. That is, large eutectic composition substrates should be gradually preheated to a desired laser treatment temperature and cooled down without deterioration. Estepa and de la Fuente [26] have recently patented a continuous furnace for laser processing ideally fitting this purpose and making it possible to process large planar surface areas.

The resistance of a dense ceramic material to thermal stress is strongly dependent on sample size and in the present case on the width of the sample to be processed. Wider samples processed with longer line focussed laser beams require even more careful control of preheating.

This study is addressed to optimize the preheating conditions of directional laser resolidification on wide and dense ceramic eutectic surfaces in order to minimize thermal shock and to obtain large defect-free surfaces with eutectic microstructure. Obtained microstructure observation was performed to evaluate the resolidification 
process. Possible deterioration of the obtained substrates due to the presence of thermal shock was evaluated by means of fracture tests.

\section{EXPERIMENTAL}

The eutectic composition ceramic substrates were produced by slip casting using porous plaster moulds. Stable water based suspensions loaded with 30 vol.\% solids loading and Polyacrylic acid based polyelectrolyte (PAA, Duramax D-3005, Rohm and Haas, USA) as a stabilizing agent were prepared with tetragonal zirconia - alumina ( $\mathrm{t}-\mathrm{ZrO}_{2}$ $\mathrm{Al}_{2} \mathrm{O}_{3}$ ) eutectic composition. In order to increase the optical absorption in the near infrared and thus to have the possibility to use different type of laser systems including a high power diode laser on the same samples, the eutectic composition was doped with $\mathrm{Mn}_{2} \mathrm{O}_{3}$. The composition of the oxide mixture was as follows: $\mathrm{Al}_{2} \mathrm{O}_{3} 62.95$ mol.\%, $\mathrm{ZrO}_{2}$ 35.89 mol.\%, $\mathrm{Y}_{2} \mathrm{O}_{3} 1.11 \mathrm{~mol} \%$ and $\mathrm{Mn}_{2} \mathrm{O}_{3} 0.05$ mol.\% as dopant. $\alpha-\mathrm{Al}_{2} \mathrm{O}_{3}$ (Ceralox, HPA-0.5, USA), with mean particle size of $0.35 \mu \mathrm{m}$ and specific surface area of 9.5 $\mathrm{m}^{2} / \mathrm{g}, \mathrm{t}-\mathrm{ZrO}_{2}$ stabilised with $3 \mathrm{~mol} \% \mathrm{Y}_{2} \mathrm{O}_{3}$, (TZ3YS, TOSOH, Japan), with a mean particle size of $0.4 \mu \mathrm{m}$ and a specific surface area of $6.7 \mathrm{~m}^{2} / \mathrm{g}$, and $\mathrm{Mn}_{2} \mathrm{O}_{3}$ (SigmaAldrich, 99.5\%) were used as starting powders. After slip casting and drying in air for 24 hours, the obtained substrates reached $\sim 54 \%$ of theoretical density and were machined to the desired geometry. Sintering was carried out using heating and cooling rates of $2^{\circ} \mathrm{C} / \mathrm{min}$ up to the sintering temperature of $1550^{\circ} \mathrm{C}$ and a dwell time of $2 \mathrm{~h}$. No substantial warping of plates upon densification was observed thus no further machining was needed. The final substrates reached $98 \%$ of theoretical density $\left(\rho_{\text {sintered }}=4.5 \pm 0.1\right.$ $\mathrm{g} / \mathrm{cm}^{3}$ ) with final aproximate dimensions of $40 \times 40 \times 6 \mathrm{~mm}$.

The directional laser surface melting process was performed using a Rofin-Sinar $350 \mathrm{~W}$ SLAB-type $\mathrm{CO}_{2}$ laser emitting at a wavelength of $10.6 \mu \mathrm{m}$. The laser beam was directed 
through an optical system of lenses and mirrors to form a continuous line (Figure 1a) of adjustable length (up to $70 \mathrm{~mm}$, along the $y$ direction) and fixed thickness (1 mm along the $x$ direction). The focusing system employed has a large focal length so as to allow reaching samples treated inside a high temperature furnace (Figure 1b) without causing thermal damage to the laser and adjacent equipment [26]. The line had a uniform power density distribution along the $\mathrm{Y}$ direction and was incident at a normal angle to the sample and in the orientation shown in Figure 1b. The stage travelling speed (traverse rate) was established at $1000 \mathrm{~mm} \cdot \mathrm{h}^{-1}$. Processing was carried out on preheated samples to temperatures between 1000 and $1200{ }^{\circ} \mathrm{C}$ with preheating and cooling down rates of $20^{\circ} \mathrm{C} / \mathrm{min}$

Plates with a resolidified eutectic layer were ground from the opposite side of the sample in order to obtain a final thickness of $3 \mathrm{~mm}$ ( $z$ direction, Figure 1a). In addition, they were cut in the transversal orientation to the laser line pass ( $y z$ plane cuts, Figure 1b) to obtain $40 \times 4 \times 3 \mathrm{~mm}$ geometry samples. Sample corners on the resolidified eutectic layer side (subjected to tensile stress during the flexure strength test) were grounded to avoid fracture initiation from defects related to final sample preparation steps. Reference samples with the same geometry were prepared from as sintered substrate plates without the directional laser resolidification treatment. The same, above described, fracture strength sample preparation procedure was applied, leaving the as sintered substrate surface to be subjected to tensile stress during the flexure strength test. Flexure strength was evaluated using a self aligning three-point bending test configuration with a $30 \mathrm{~mm}$ span between supporting rods in an Instron 4505 servomechanical testing machine. All tests were performed in air under stroke control at a cross-head speed of $0.05 \mathrm{~mm} / \mathrm{min}$. The average flexure strength values were calculated from the maximum load recorded in the test for five samples as long as that the fracture 
started in the nearby zone subjected to maximum tensile stress and taking into account the cross section geometry of each sample. The reported error is the standard deviation. The microstructure of solidified eutectic layers and fractured surfaces were characterized using a JEOL JSM6400 scanning electron microscope (SEM). Obtained microstructure in $x Z$ plane was characterized using sample sections polished down to 1 $\mu \mathrm{m}$.

\section{RESULTS AND DISCUSSION}

In previous attempts, laser resolidified $\mathrm{t}-\mathrm{ZrO}_{2}-\mathrm{Al}_{2} \mathrm{O}_{3}$ ceramic surfaces with larger than 1 $\mathrm{cm}$ in width geometry and preheated to $980{ }^{\circ} \mathrm{C}$ exhibited large scale defects due to thermal shock effects. The extensive cracks observed propagated along the longitudinal direction (parallel to the sample travelling direction, $x$ axis) throughout the whole eutectic ceramic substrate. As a possible solution to this drawback, preheating of the samples within the 1000 to $1200^{\circ} \mathrm{C}$ temperature range was chosen.

A preheating temperature of $1000{ }^{\circ} \mathrm{C}$ resulted insufficient to avoid thermal shock damage. Extensive cracking of the ceramic substrates during remelting of the surface layer was observed. The fact that cracks were generated at the same instance the laser beam touched the sample clearly indicated that the preheating temperature was not sufficient. By increasing the preheating temperature up to $1100^{\circ} \mathrm{C}$, fracture of the substrate during laser melt processing was avoided, but crack formation was detected during the cooling down ramp. These cracks appeared along $x Z$ planes and were located at an almost constant distance of $14-18 \mathrm{~mm}$ from each other. Thermo-mechanical calculations indicate that these cracks form due to stresses generated in the ceramic bulk, near the interface between the resolidified layer and the remaining ceramic substrate [27]. An order of magnitude estimate of the local thermal gradient around the 
drop-shaped melt has been obtained from pyrometric measurements of the temperature of the melt. Figure 2 gives the temperature of the melt (right axis) and the melt depth (left axis) as a function of the linear power density for preheating temperatures of $1100^{\circ} \mathrm{C}$ and at travelling rates of $1000 \mathrm{~mm} / \mathrm{h}$. Larger power densities yield larger melt depths and larger melt overheating. Assuming that the measured temperatures are the maximum melt temperatures, the thermal gradient across the molten drop can be calculated. Thermal gradients between 260 and $390 \mathrm{~K} / \mathrm{mm}$ are obtained $(260 \mathrm{~K} / \mathrm{mm}$ for $58 \mathrm{~W} / \mathrm{cm}$ linear power density with $1100{ }^{\circ} \mathrm{C}$ preheating.) At processing rates of 1000 $\mathrm{mm} / \mathrm{h}$, we obtain cooling rates around $100 \mathrm{~K} / \mathrm{s}$. This thermal gradient will be of the same order of magnitude as the thermal gradient that the solid sample adjacent to the melt will be subjected to. The latter are the responsible ones for the development of thermal stress during cooling and sample cracking. The magnitude of accumulated stress will depend on the thermomechanical material response.

In order to diminish these residual stresses below the fracture stress, the substrate preheating temperature was further increased to $1200^{\circ} \mathrm{C}$. At this temperature ceramics tend to show some plasticity thus the accommodation and relaxation of the above mentioned residual stress is expected. As shown in Figure 3, by using $1200{ }^{\circ} \mathrm{C}$ preheating temperature, a dense defect free sample (at this level of observation) with smooth resolidified layer is obtained. This fact confirms the previous hypothesis that the principal cause of the observed crack formation during cooling down is due to macrostresses formed between the resolidified layer and the remaining ceramic substrate while processing. If that would be the case of thermal shock caused by relatively fast cooling down of dense substrate then it would be even more pronounced due to higher preheating temperature. The relaxation of the previously mentioned stresses below the critical value and at the same time elimination of crack formation within substrates of 
$40 \mathrm{~mm}$ in width, indicates that there is no limit in the geometry of the surface to be treated, as long as sufficient laser power density is employed to obtain material melting. Table 1 summarizes the depth of the remelted layers obtained using fixed laser irradiances of $580 \mathrm{~W} / \mathrm{cm}^{2}$ for all three temperatures investigated. Substantial increase in remelted layer thickness with increasing preheating temperature is obtained due to the preheating temperature contribution to eutectic melting.

The observation with SEM of the polished cross sections of eutectic substrates processed at $1200^{\circ} \mathrm{C}$ shows the formation of a dense layer, with thickness around 400 $\mu \mathrm{m}$, free of cracks and delamination defects (Fig. 4.a). The microstructure (Fig. 4.b-c) consists of elongated eutectic cells with lamellar internal microstructure, the same that was obtained for $\mathrm{t}-\mathrm{ZrO}_{2}-\mathrm{Al}_{2} \mathrm{O}_{3}$ eutectics with a processing speed of $1000 \mathrm{~mm} / \mathrm{h}$ [22] with lower preheating temperatures $\left(980^{\circ} \mathrm{C}\right)$. Figure $4 \mathrm{c}$ also shows the presence of $\mathrm{Al}_{2} \mathrm{O}_{3}$ (dark phase) primary dendrites that grow near to the layer-ceramic interphase, probably a consequence of a slight shift of the ceramic composition from the eutectic compositions towards larger $\mathrm{Al}_{2} \mathrm{O}_{3}$ contents. The eutectic cells are oriented from the bottom towards the top of the layer in its lower part, and form left to right in its upper part, in the region near its surface (fig. 4b). This corresponds to a growth direction perpendicular to the solid-liquid interface which is drop-shaped. Consequently, overall, the alignement is parallel to the sample traverse direction (X-direction in figure 1). Previous mechanical studies have shown that the weakest areas in $\mathrm{Al}_{2} \mathrm{O}_{3}$-zirconia eutectics are the intercellular areas [22], which are oriented parallel to the traverse direction along which also cooling crack formation is more probable.

The mechanical performance of the eutectic plates processed with an optimum preheating temperature of $1200{ }^{\circ} \mathrm{C}$ was evaluated by carrying out fracture strength measurements. Bars were cut out from the plates in the perpendicular direction to 
sample travelling ( $y z$ plane, Fig. 1a), so that any unnoticed crack formation along the sample travelling direction would be revealed by the fracture test. The reference ceramic samples showed the typical fracture origins in regions near the surface (Fig. 5.a) subjected to tensile stress. From Figure $5 \mathrm{~b}$ it is possible to observe that the laser surface melting proved to remove surface defects, thus forcing the fracture to start from defects below or at the interface of the resolidified layer with the substrate. Moreover, the fracture origin was associated, in all cases, to defects present within the non-melted ceramic microstructure. The average fracture strength values were determined to be 530 $\pm 130 \mathrm{MPa}$ for reference samples and $503 \pm 20 \mathrm{MPa}$ for samples with a resolidified layer. Although from these results no change in average fracture strength values is observed, a significant decrease in standard deviation for ceramic samples with a resolidified layer is revealed. Further work is under way to evaluate the surface remelting effect on the Weibull distribution of fracture strength of ceramics substrates.

\section{CONCLUSIONS}

Wide $(40 \mathrm{~mm}) \mathrm{t}-\mathrm{ZrO}_{2}-\mathrm{Al}_{2} \mathrm{O}_{3}$ eutectic ceramic plates were laser processed with preheating to temperatures up to $1200^{\circ} \mathrm{C}$. A defect free, $0.4 \mathrm{~mm}$ thick resolidified layer was obtained. This indicates that the preheating temperature employed is effective in minimising thermal shock and processing stresses, so that devastating longitudinal cracks were eliminated.

By employing this process, smooth surfaces without overlapping track roughness and homogeneous microstructures are obtained. The typical refined aligned eutectic microstructure of lamellar-type $\mathrm{Al}_{2} \mathrm{O}_{3}$ and $\mathrm{YSZ}$ cells was formed within the resolidified layer. 
Fracture strength measurements confirmed the absence of longitudinal crack-type defects within the final laser remelted ceramic surface. Although no significant change in average fracture strength was observed, the decrease of its standard deviation for ceramic samples with a resolidified layer was revealed. Further work should be carried out to evaluate the surface remelting effect on the Weibull distribution of the ceramic materials.

From the results observed it is expected that $1200{ }^{\circ} \mathrm{C}$ preheating temperature permits to carry out laser remelting of dense (98\%TD) eutectic composition ceramic substrates without geometrical limitations.

\section{ACKNOWLEDGEMENTS}

The results were obtained under projects number MAT2006-13005-C03-01 and MAT2009-13979-C03-03 financed by the Spanish Government and the European Community FEDER funds. Jonas Gurauskis acknowledges the financial support provided by CSIC through I3P contract. GFF and VVL acknowledge project CEN20072014 for partial support, as well as CSIC for a JAE fellowship. DGA is acknowledged for financial support of the Laser Processing and Characterisation Excellence Research Group. The authors thak the Servicio de Microscopía Electrónica (Universidad de Zaragoza) for allowing the SEM observations. The authors acknowledge F.J. Ester for fruitful discussions in the course of this work. 


\section{REFERENCES}

1. $\quad$ S.Z. Lee, K.H. Zum-Gahr, Ceram. Int. , 20 [3] (1994) 147-157.

2. A.H. Wang, W.Y. Wang, C.S. Xie, W.L. Song, D.W. Zeng, Appl. Surf. Sci. , 227 [1-4] (2004) 104-113.

3. $\quad$ S.P. Harimkar, N.B. Dahotre, Scr. Mater., 58 [7] (2008) 545-548.

4. S. Harimkar and N.B. Dahotre. Phys. Stat. Sol. (a) 204 (2007) 1105-1113.

5. J. Lawrence, L. Li, J. Phys. D: Appl. Phys., 32 [10] (1999) 1075-1082.

6. F.J. Ester, R.I. Merino, J.Y. Pastor, A. Martin, J. Llorca, J. Am. Ceram. Soc. , 91 [11] (2008) 3552-3559.

7 K. Poser, K-H. Zum Gahr and J. Schneider, Wear 259 (2005) 529-538.

8. K.H. Zum Gahr, J. Schneider, Ceram. Int., 26 [4] (2000) 363-370.

9. Y. Umezu, R.L. Lehman, J. Wagner, P. Biswas, D.E. Murnick, J. Am. Ceram. Soc. , 82 [6] (1999) 1425-1428.

10. D.H. Matthiesen, W.T. Petuskey, J. Am. Ceram. Soc. , 68 [5] (1985) C114C116.

11. V.V. Lennikov, J.M. Pedra, J.J. Gomez, G.F. de la Fuente, J.B. Carda, Solid State Sci. , 9 [5] (2007) 404-409.

12 G. Antou, G. Montavon, F. Hlawka, A. Cornet, C. Becker, D. Ruch and A. Riche. Surf. Coat. Techn. 200 (2006) 6062.

13. G. Antou, G. Montavon, F. Hlawka, A. Cornet, C. Coddet and F. Machi. J. Europ. Ceram. Soc. 26 (2006) 3583.

14. S.Z. Lee, K.H. Zumgahr, Materialwiss. Werkstofftech., 23 [4] (1992) 117-123.

15. L. Bradley, L. Li, F.H. Stott, Mater. Sci. Eng., A, 278 [1-2] (2000) 204-212.

16. D. Triantafyllidis, J.R. Bernstein, L. Li, F.H. Stott, J. Laser Appl. , 15 [1] (2003) 49-54.

17. D. Triantafyllidis, L. Li, F.H. Stott, Surf. Coat. Technol., 201 [6] (2006) 31633173.

18. R. Campana, A. Larrea, J.I. Pena, V.M. Orera, J. Eur. Ceram. Soc., 29 [1] (2009) 85-90.

19. J. Llorca, V.M. Orera, Prog. Mater Sci. , 51 [6] (2006) 711-809.

20. A. Larrea, G.F. de la Fuente, R.I. Merino, V.M. Orera, J. Eur. Ceram. Soc., 22 [2] (2002) 191-198.

21. C.O. Hulse, J.A. Batt, Rep. UARL N-910803-10, (1974).

22. J.Y. Pastor, J. Llorca, P. Poza, I. de Francisco, R.I. Merino, J.I. Pena, J. Eur. Ceram. Soc., 25 [8] (2005) 1215-1223.

23. A. Larrea, V.M. Orera, R.I. Merino, J.I. Pena, J. Eur. Ceram. Soc., 25 (2005) 1419.

24. R.I. Merino, J.I. Pena, M.A. Laguna-Bercero, A. Larrea, V.M. Orera, J. Eur. Ceram. Soc., 24 [6] (2004) 1349-1353.

25. A.V. Polotai, J.F. Foreman, E.C. Dickey, K. Meinert, Int. J. Appl. Ceram. Technol. , 5 [6] (2008) 610-617.

26. L.C. Estepa, G.F. de la Fuente (2007).Patent WO2007101900.

27. F.J. Ester, Private communication (2008). 
Table 1. Depth of the remelted layer under laser irradiances of $580 \mathrm{~W} / \mathrm{cm}^{2}$ and a traverse rate of $1000 \mathrm{~mm} \cdot \mathrm{h}^{-1}$.

\begin{tabular}{|c|c|}
\hline $\begin{array}{c}\text { Preheating temperature } \\
\left({ }^{\circ} \mathrm{C}\right)\end{array}$ & $\begin{array}{c}\text { Depth of remelted layer } \\
(\mu \mathrm{m})\end{array}$ \\
\hline 1000 & $150 \pm 10$ \\
\hline 1100 & $240 \pm 10$ \\
\hline 1200 & $400 \pm 20$ \\
\hline \hline
\end{tabular}


Figure Captions:

Figure 1. Schematics of substrate treatment with laser quasi continuous line (a) and experimental set up of laser zone melting process (b).
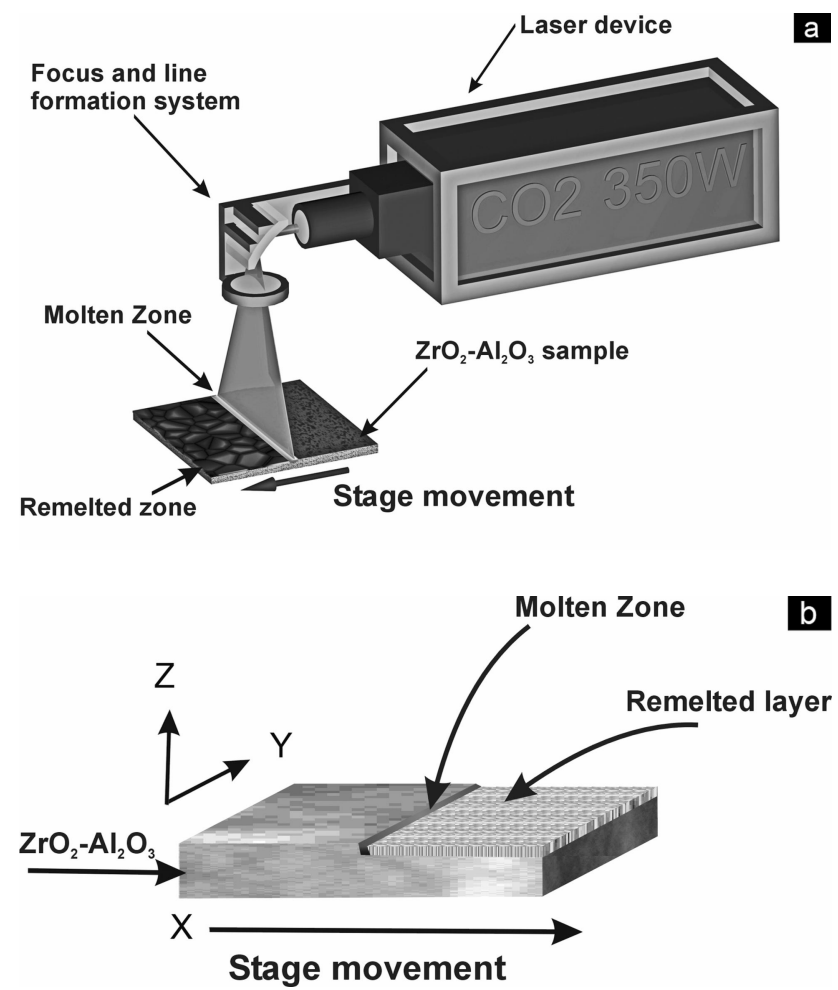
Figure 2. Melt depth (left axis) and melt temperature (right axis) as a function of laser power density when the $\mathrm{Al}_{2} \mathrm{O}_{3}-\mathrm{ZrO}_{2}\left(\mathrm{Y}_{2} \mathrm{O}_{3}\right)$ samples are preheated at $1100{ }^{\circ} \mathrm{C}$. The lines are guides to the eye.

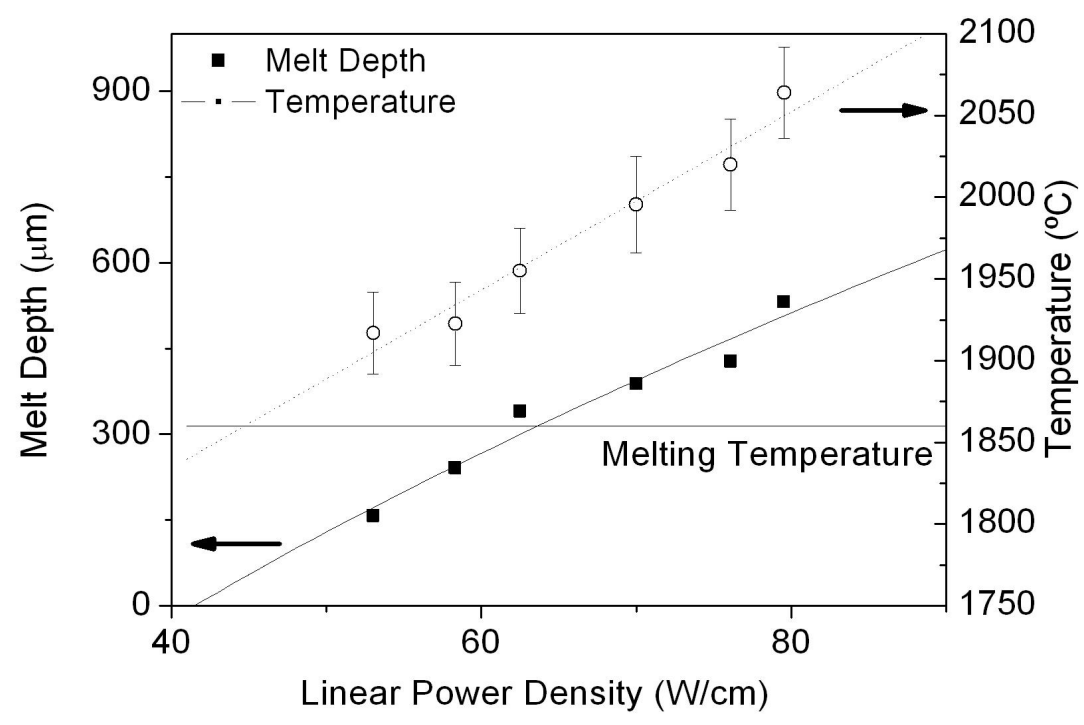

Figure 3. Laser surface remelted ceramic monolith processed under optimum conditions and cooled down to room temperature. No structural defects arising from laser remelting can be observed at this scale.

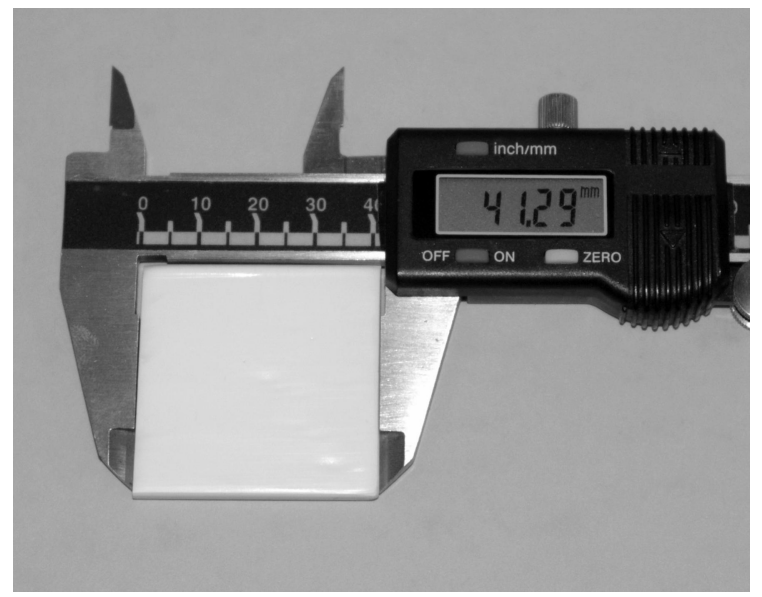


Figure 4. SEM backscattered images taken at the polished cross section (xz plane) of the $\mathrm{Al}_{2} \mathrm{O}_{3}$-YSZ plate with a remelted layer: (a) general view of the $\sim 400 \mu \mathrm{m}$ layer formed,(b) the colonies formed and (C) detail of the colonies formed $\left(\mathrm{Al}_{2} \mathrm{O}_{3}\right.$ - dark phase, YSZ - bright phase).
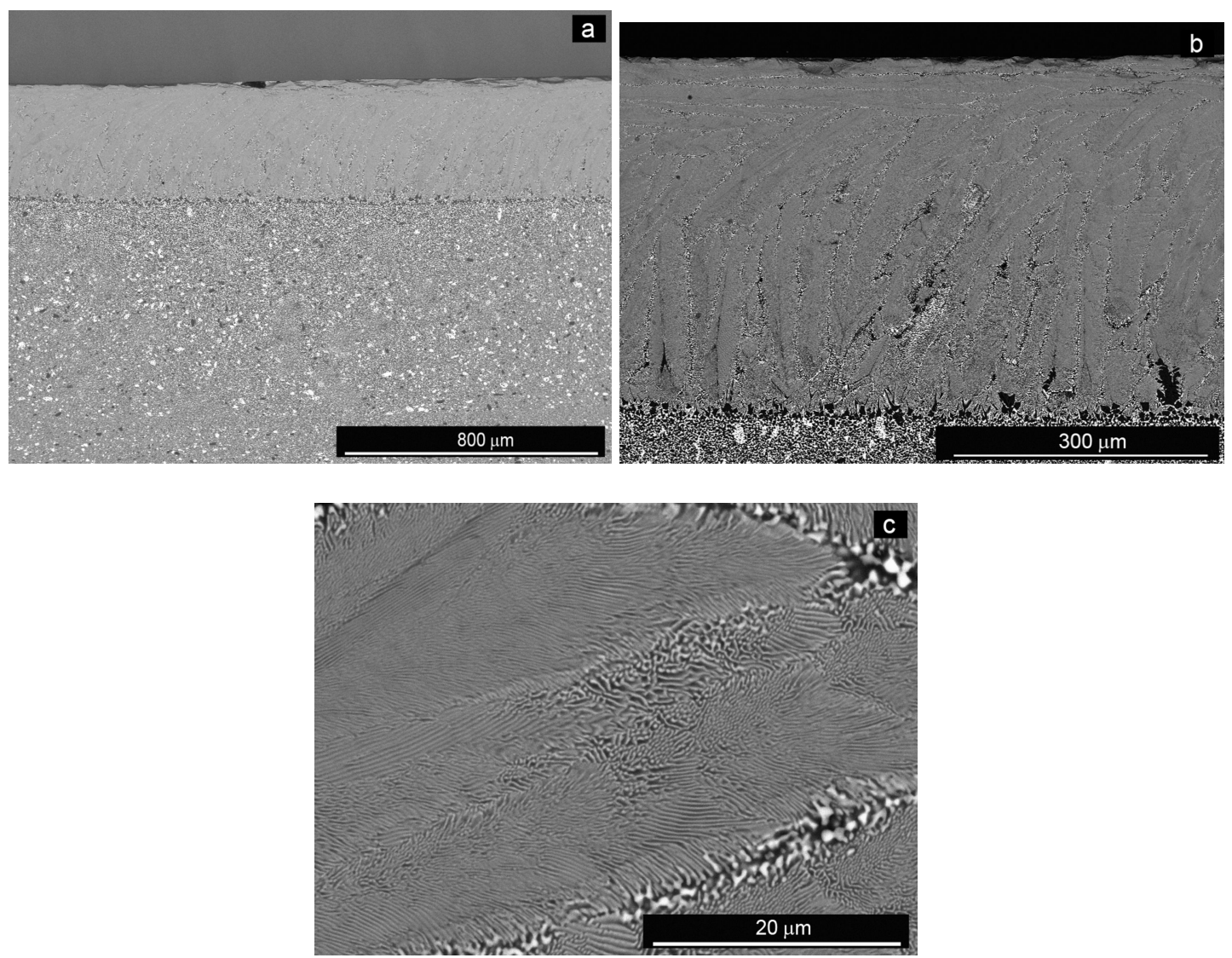
Figure 5. SEM images of the typical critical fracture defects corresponding to: (a) reference sample without remelted layer and (b) sample with laser remelted layer. The arrows indicate the fracture initiation area. As can be observed, remelting of the surface removes the superficial defects and forces the fracture to start within the zone below the remelted layer.
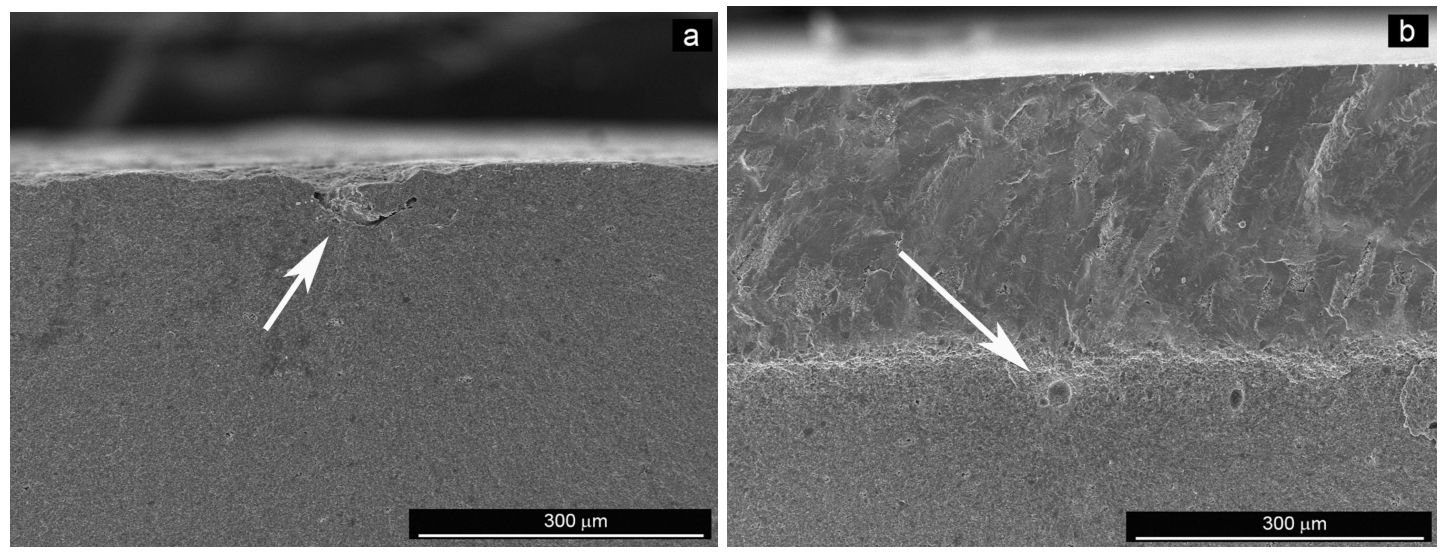